\title{
Prevalence of gastroesophageal reflux in infants with recurrent brief apneic episodes
}

\author{
Shahid Sheikh $M D^{1}$, Thomas C Stephen $\mathrm{MD}^{2}$, Barbara Sisson $\mathrm{MD}^{3}$ \\ Divisions of ${ }^{1}$ Pediatric Pulmonary Medicine, ${ }^{2}$ Pediatric Gastroenterology and ${ }^{3}$ Ambulatory \\ Care, Department of Pediatrics, University of Louisville, Louisville, Kentucky, USA
}

\begin{abstract}
S Sheikh, TC Stephen, B Sisson. Prevalence of gastroesophageal reflux in infants with recurrent brief apneic episodes. Can Respir J 1999;6(5):401-404.
\end{abstract}

BACKGROUND: Apnea in an infant can be a diagnostic dilemma for the treating pediatrician. It is suggested that in some infants, gastroesophageal reflux (GER) might be a factor in the pathogenesis of apnea, although its role as a cause of apnea is still controversial.

OBJECTIVE: To evaluate the prevalence of GER in infants presenting with recurrent brief apneic periods.

PATIENTS AND METHODS: A retrospective review of the medical records of all the infants who underwent prolonged esophageal $\mathrm{pH}$ studies for brief apneic episodes $(\mathrm{n}=105)$ at the Kosair Children's Hospital in the six years from January 1992 to December 1997 was performed. Infants presenting with apparent life-threatening episodes were excluded.

RESULTS: Of 105 infants, 72 (68.6\%) were younger than two months of age and $22(21 \%)$ were born preterm. Fifty of 105 infants (47.6\%) had positive esophageal $\mathrm{pH}$ studies for acid reflux. Among infants with positive $\mathrm{pH}$ studies, only 21 (42\%) had associated gastrointestinal or feeding complaints. CONCLUSION: GER is present in a large number of infants presenting with brief apneic episodes. Though the relationship between the two is still not fully established, GER may be a significant risk factor for such apneic episodes in infants.

Key Words: Apnea; Esophageal pH; Gastroesophageal reflux (GER); Infants
Fréquence du reflux gastro-oesophagien chez les nourrissons qui présentent de brefs épisodes récurrents d'apnée

CONTEXTE : Les épisodes d'apnée chez les nourrissons peuvent poser un problème diagnostique pour le pédiatre traitant. Il semblerait que, chez certains enfants, le reflux gastro-oesophagien (RGO) soit un facteur de pathogenèse d'apnée, bien que ce rôle fasse encore l'objet de controverse.

OBJECTIF : Évaluer la fréquence du RGO chez les nourrissons qui présentent de brefs épisodes récurrents d'apnée.

PATIENTS ET MÉTHODE : On a procédé à une analyse rétrospective des dossiers médicaux de tous les nourrissons qui ont subi des examens prolongés pour analyse $\mathrm{du} \mathrm{pH}$ oesophagien en raison de brefs épisodes d'apnée $(\mathrm{n}=105)$ au Kosair Children's Hospital entre janvier 1992 et décembre 1997. Ont été exclus de l'étude les enfants qui présentaient des épisodes constituant manifestement un danger de mort.

RÉSULTATS : Des 105 nourrissons, 72 (68,6\%) avaient moins de deux mois et 22 (21\%) étaient nés prématurément. Dans 50 cas sur $105(47,6 \%)$, les analyses du pH oesophagien ont confirmé la présence de reflux acide. Parmi les enfants dont les résultats des examens se sont avérés positifs, seulement 21 (42\%) présentaient des symptômes gastro-intestinaux ou des problèmes d'allaitement associés.

CONCLUSION : Un grand nombre de nourrissons qui présentent de brefs épisodes d'apnée souffrent également de RGO. Bien que le lien entre les deux phénomènes ne soit pas clairement établi, le RGO peut s'avérer un facteur de risque important d'épisodes d'apnée chez les nourrissons. 
B etween $40 \%$ and $50 \%$ of infants with gastroesophageal reflux (GER) present with respiratory symptoms $(1,2)$. The relationship of GER to respiratory problems, such as persistent wheezing and chronic cough, is well established (3-7). In infants, studies have suggested a relationship between apnea and GER (8-14), but the temporal association is still controversial (15-17). Despite the lack of conclusive evidence, apnea associated with reflux remains a common indication for fundoplication, and this approach is supported by a significant postoperative decrease in the frequency of apneic episodes (18-19). Because the resolution of GER is associated with improvement in apnea episodes, a relationship between the two is possible.

GER is not only postulated to cause obstructive apnea but is also implicated in central and mixed apnea $(11,20$ 24). Apnea may be mediated by distal esophageal afferents and laryngospasm secondary to chemoreflexes (24-26). In a large prospective study, it was observed that some infants, who later were sudden infant death syndrome victims, had an increased number of brief apneic episodes (27), although the relationship, if any, between the two was not clear. One group reported a relationship between brief apneic episodes while sleeping and GER (28), and other groups noted a relationship between awake apnea and GER or regurgitation $(11,13,15)$.

We undertook the present study to evaluate the prevalence of GER in infants presenting with recurrent brief apneic episodes (less than $20 \mathrm{~s}$ ). Infants with the history suggestive of prolonged apnea (greater than $20 \mathrm{~s}$ ) or apparent lifethreatening episodes were excluded.

\section{PATIENTS AND METHODS}

The medical records of 105 consecutive infants with a history of recurrent brief apneic episodes, who underwent prolonged esophageal $\mathrm{pH}$ studies to rule out gastroesophageal reflux at the Kosair Children's Hospital, Louisville, Kentucky between January 1992 to December 1997, were reviewed. In all infants, recurrent brief apneic episodes had been observed by the parents at home; these episodes were estimated to be less than $20 \mathrm{~s}$ in duration and were not associated with limpness, cyanosis or pallor. All infants were referred for a prolonged esophageal $\mathrm{pH}$ study for acid reflux by eight local pediatricians. The episodes of apnea resolved either spontaneously or with minimal physical stimulation. Infants in whom apnea was associated with limpness, cyanosis, pallor or bradycardia (suggestive of apparent life-threatening episodes) and those who required resuscitation were excluded.

Infants with the diagnosis of awake apnea had apneic episodes while awake and alert, and were either being held by the parent or were lying down. In infants who had apneic episodes while lying down, their position (supine or prone) was not documented in most cases. Infants with sleep apnea were sleeping at the time of the apneic episodes. Infants with both awake and asleep apnea had brief apneic episodes while both awake and sleeping.

Details of birth history, associated gastrointestinal symp-
TABLE 1

Demographic parameters of infants with apnea

\begin{tabular}{lc}
\hline Parameters & Value \\
\hline Number & 105 \\
Sex (male to female) & $63: 42$ \\
Age at first episode (months) & $1.7 \pm 1.4$ \\
& (range 1 week to 9) \\
Age at pH study (months) & $2.7 \pm 2.4$ \\
& (range 3 weeks to 9) \\
On gastroesophageal reflux medications & None \\
at the time of pH study & \\
Smoking exposure & $33 / 78(42 \%)$ \\
Associated gastrointestinal symptoms & $46(44 \%)$ \\
Time of apneic episodes & \\
While awake & $60(57 \%)$ \\
While asleep & $30(28.5 \%)$ \\
$\quad$ Mixed & $15(14.5 \%)$ \\
Gestational age & \\
Born at term & $83(79 \%)$ \\
Born preterm (less than 37 weeks) & $22(21 \%)$ \\
Positive pH studies & $50(47.6 \%)$ \\
\hline
\end{tabular}

Data regarding age is expressed in means $\pm S D$

toms (spitting, vomiting, abdominal pain, etc), age at the onset of apneic episodes, timing of the apneic episodes (awake, asleep or both), age at which prolonged esophageal $\mathrm{pH}$ studies were completed, history of exposure to cigarette smoking and results of esophageal $\mathrm{pH}$ studies were obtained from the medical records. A standard technique was used for all $\mathrm{pH}$ studies, using criteria described by Sondheimer (5). An esophageal antimony $\mathrm{pH}$ electrode was placed 3 to $4 \mathrm{~cm}$ above the gastroesophageal junction, and a chest roentgenogram was taken to confirm and, if necessary, adjust the position. Activity and feeding were continued as usual during the tests. All esophageal $\mathrm{pH}$ studies were done as an in-patient for 23 h. Before the test, the $\mathrm{pH}$ probe was calibrated at $\mathrm{pH} 1$ and 7 to ensure accuracy. Significant acid reflux was defined as a percentage of time for which esophageal $\mathrm{pH}$ was below 4 , of more than 6\% (normal 3.4\%; 95th percentile).

Statistical methods: For comparison between the groups, Student's $t$ test was used. For categorical variables, $\chi^{2}$ analysis was used and $\mathrm{P}<0.05$ was considered significant.

\section{RESULTS}

Prolonged esophageal $\mathrm{pH}$ studies were performed on 105 infants with the history of recurrent brief apneic episodes (Table 1). Of 105 infants, 72 (68.5\%) were younger than two months of age at the time of esophageal $\mathrm{pH}$ studies. Eightythree infants $(79 \%)$ were born at term, and $22(21 \%)$ were born preterm (less than 37 weeks of gestation). Sixty-three (60\%) were males and 42 females. Fifty of 105 infants (47.6\%) had positive $\mathrm{pH}$ studies, but none of the infants had apnea episodes during the duration of the $\mathrm{pH}$ study.

Among infants younger than two months of age, 31 of 72 (43\%) infants had GER. Among the infants older than two months of age (two to nine months), 19 of 33 (57.6\%) infants had GER. There were no statistically significant demo- 
TABLE 2

Demographic parameters of infants with or without gastroesophageal reflux (GER)

\begin{tabular}{lcc}
\hline & $\begin{array}{c}\text { Infants with GER } \\
(\mathbf{n}=50)\end{array}$ & $\begin{array}{c}\text { Infants without } \\
\text { GER }(\mathbf{n}=55)\end{array}$ \\
\hline Sex (male to female) & $28: 22$ & $35: 20$ \\
Age at first episode & $1.96 \pm 1.68$ & $1.52 \pm 1.23$ \\
$\quad$ (months) & & \\
Age at pH study (months) & $2.98 \pm 2.73$ & $2.27 \pm 2.20$ \\
Smoking exposure & $18 / 42(43 \%)$ & $15 / 36(43 \%)$ \\
On GER medications at the & None & None \\
$\quad$ time of pH study & & \\
Associated gastrointestinal & $21(42 \%)$ & $25(45 \%)$ \\
$\quad$ symptoms & & \\
Time of apneic episodes & $32(64 \%)$ & $28(51 \%)$ \\
$\quad$ While awake & $10(20 \%)$ & $20(36 \%)$ \\
$\quad$ While asleep & $8(16 \%)$ & $7(13 \%)$ \\
$\quad$ Both awake and asleep & & \\
Gestational age & & \\
$\quad$ Born at term & & \\
Born preterm & $91(82 \%)$ & $13(23 \%)$ \\
\hline
\end{tabular}

Data regarding age is expressed as means $\pm S D$

graphic differences between the infants with positive $\mathrm{pH}$ studies and infants with negative $\mathrm{pH}$ studies for both age groups (Table 2).

Infants with GER had significantly higher mean values of the parameters of $\mathrm{pH}$ studies for acid reflux compared with infants without GER ( $\mathrm{P}<0.0005$ for all parameters) (Table 3).

\section{DISCUSSION}

GER has been implicated in apnea with or without apparent life-threatening episodes (8-14,28-34). GER-induced apnea may be obstructive or central apnea (12,14,35-37). Possible mechanisms may involve stimulation of superior laryngeal nerve afferents $(35,37)$, laryngeal and nasopharyngeal receptors (38), and reflex bradycardia (39). It has also been suggested that the esophageal pain caused by GER may trigger beta-endorphin release, which in turn decreases respiratory drive and alters chemolaryngeal reflexes $(40,41)$. Other postulated mechanisms are vagal nerve stimulation (42), GER-induced hypoxemia (29) and anaphylaxis to milk antigens (33). Wetmore (37) has demonstrated acid-induced laryngospasm, mimicking apnea, in animals by instillation of acid into the larynx. It is, therefore, possible that exposure of the larynx area to acid present in stomach contents may stimulate the superior laryngeal nerve and trigger apnea.

In infants, airways are protected during regurgitation by anatomic closure of the upper airways at the level of the larynx, followed by the pharyngeal swallow (43). In some infants, brief respiratory pauses during swallowing may represent a secondary airway protective mechanism (14). Airway protective mechanisms during regurgitation, with or without GER, take precedence over ventilation, and, in some infants, these respiratory pauses and the airway closure following regurgitation can occasionally be prolonged and present as clinical apnea (13). An increased frequency of brief apnea is observed in infants during GER and in infants after regurgita-
TABLE 3

Prolonged esophageal pH study parameters

\begin{tabular}{|c|c|c|c|}
\hline & $\begin{array}{l}\text { Infants } \\
\text { with GER }\end{array}$ & $\begin{array}{c}\text { Infants without } \\
\text { GER }\end{array}$ & $\mathbf{P}$ \\
\hline $\begin{array}{l}\text { Number of GER } \\
\text { episodes }\end{array}$ & $49 \pm 24.6$ & $13 \pm 8.8$ & $<0.0005$ \\
\hline $\begin{array}{l}\text { Number of GER } \\
\text { episodes longer than } \\
5 \text { mins }\end{array}$ & $6.8 \pm 4.7$ & $1.2 \pm 1.1$ & $<0.0005$ \\
\hline $\begin{array}{l}\text { Longest duration of } \\
\text { GER episodes } \\
\text { (mins) }\end{array}$ & $43 \pm 36$ & $8.4 \pm 6.4$ & $<0.0005$ \\
\hline $\begin{array}{l}\text { Period of time } \mathrm{pH} \text { was } \\
\text { less than } 4 \text { (mins) }\end{array}$ & $196 \pm 113$ & $32.8 \pm 18.6$ & $<0.0005$ \\
\hline $\begin{array}{l}\text { Time that } \mathrm{pH} \text { was less } \\
\text { than } 4(\% \text { of total } \\
\text { time of } \mathrm{pH} \text { study }\end{array}$ & $16 \pm 9.36$ & $2.65 \pm 1.5$ & $<0.0005$ \\
\hline
\end{tabular}

tion $(13,15)$, suggesting that during the episodes of GER, the gastric contents may occasionally come into contact with laryngeal chemoreceptors, leading to reflex apnea, which may be variable in duration. Thus, abnormal upper airway stimuli or overactive upper airway protective reflexes may be responsible for the apneic episodes in some infants (44). Silent GER can trigger both mechanisms by introduction of passively refluxed gastric contents in the pharynx, leading to apneic events.

Brief apneic episodes can occur either while the infant is sleeping sleep or while he or she is awake. It has been noted that many infants with awake apnea may have underlying GER, and most of these infants have obstructive apnea probably secondary to laryngospasm from gastric contents reaching the pharynx (11). Although it is postulated that apnea during sleep may be secondary to some abnormality in regulation of the control of breathing (45), it was also noted that stimulation of chemoreceptors in the proximal esophagus or larynx can result in respiratory depression (35). Recently, an association between brief apneic episodes while asleep and GER was observed (28). In our study, 32 of 60 $(53 \%)$ infants with awake apnea and 10 of $30(33 \%)$ infants with apnea while asleep had significant GER. Eight of 15 (53\%) infants with both awake and asleep apnea also had significant GER. In our study, 21 (42\%) infants with GER had symptoms suggestive of GER, such as frequent regurgitation and vomiting, feeding difficulties, sleeping disruptions and/or poor weight gain, along with apnea. Twenty-nine infants $(58 \%)$ did not have external symptoms of GER other than apnea, suggesting that apnea may indeed be an occult manifestation of GER. Interestingly, almost the same percentage of infants without GER had similar gastrointestinal symptoms, suggesting that these symptoms may not provide adequate criteria for the diagnosis of GER.

We looked at the yield of prolonged esophageal $\mathrm{pH}$ studies, completed to establish a diagnosis of GER in infants presenting with brief apnea without apparent life-threatening episode. Because $47 \%$ of infants in our study had evidence of significant acid GER, it is possible that apnea may only be in- 
duced by GER episodes in which gastric material reaches the chemoreceptors present in the proximal esophagus or larynx.

Brief uncomplicated apneic episodes are common in infants, and we do not infer that all infants with uncomplicated brief apnea need an esophageal $\mathrm{pH}$ probe, and if positive, antireflux therapy. Although there is a high incidence of GER in infants with brief apneic episodes, this paper does not estab-

\section{REFERENCES}

1. Shepherd RW, Wren J, Evans S, Lander M, Ong TH. Gastroesophageal reflux in children. Clinical profile, course and outcome with active therapy in 126 cases. Clin Pediatr 1987;26:55-60.

2. Vandenplas Y. Esophageal $\mathrm{pH}$ Monitoring for Gastroesophageal Reflux in Infants and Children. Chichester: John Wiley, 1992.

3. Eid NS, Shepherd RW, Thomson MA. Persistent wheezing and gastroesophageal reflux in infants. Pediatr Pulmonol 1994;18:39-44.

4. Platzker AC. Gastroesophageal reflux and respiratory illness. In: Chernick V, Kendig EL, eds. Kendig's Disorders of the Respiratory Tract in Children. Philadelphia: WB Saunders Inc, 1990:466-75.

5. Sondheimer JM. Gastroesophageal reflux: update on pathogenesis and diagnosis. Pediatr Clin North Am 1988;35:103-16.

6. Christie DL, O'Grady LR, Mack DU. Incompetent lower esophageal sphincter and gastroesophageal reflux in recurrent acute pulmonary disease of infancy and childhood. J Pediatr 1978;93:23-7.

7. Fitzgerald JM, Allen CJ, Craven MA, Newhouse MT. Chronic cough and gastroesophageal reflux. CMAJ 1989;140:520-4.

8. Herbst JJ, Book LS, Bray PF. Gastroesophageal reflux in the "near miss" sudden infant death syndrome. J Pediatr 1978;92:73-5.

9. Leape LL, Holder TM, Franklin JD, Amoury RA, Ashcraft KW. Respiratory arrest in infants secondary to gastroesophageal reflux. Pediatrics 1977;60:924-8.

10. Gomes H, Lallemand P. Infant apnea and gastroesophageal reflux. Pediatr Radiol 1992;22:8-11.

11. Spitzer AR, Boyle JT, Tuchman DN, Fox WW. Awake apnea associated with gastroesophageal reflux: A specific clinical syndrome. J Pediatr 1984;104:200-5.

12. Herbst JJ, Minton SD, Book LS. Gastroesophageal reflux causing respiratory distress and apnea in newborn infants. J Pediatr 1979;95:763-8.

13. Menon AP, Schefft GL, Thach BT. Apnea associated with regurgitation in infants. J Pediatr 1985;106:625-9.

14. Thach BT. Reflux associated apnea in infants: Evidence for a laryngeal chemoreflex. Am J Med 1997;103:120-4.

15. Walsh JK, Farrell MK, Keenan WJ, Lucas M, Kramer M. Gastroesophageal reflux in infants: relation to apnea. J Pediatr 1981;99:197-201.

16. Kahn A, Rebuffat E, Sottiaux M, Blum D, Yasik EA. Sleep apnea and acid esophageal reflux in control infants and in infants with an apparent life-threatening event. Biol Neonate 1990;57:144-9.

17. Ariagno RL, Guilleminault C, Baldwin R, Owen-Boeddiker M. Movement and gastroesophageal reflux in awake term infants with "near miss" SIDS, unrelated to apnea. J Pediatr 1982;100:894-7.

18. St Cyr JA, Ferrara TB, Thompson TR, Johnson DE, Foker JE. Nissen fundoplication for gastroesophageal reflux in infants. J Thorac Cardiovasc Surg 1986;92:661-6.

19. Harnsberger JK, Corey JJ, Johnson DG, Herbst JJ. Long-term follow up of surgery for gastroesophageal reflux in infants and children. J Pediatr 1983;102:505-8.

20. Bystrzycka E, Nail BS, Purves MJ. Central and peripheral neural respiratory activity in the mature sheep foetus and newborn lamb. Respir Physiol 1975;25:199-215.

21. Sutton D, Taylor EM, Lindeman RC. Prolonged apnea in infant monkeys resulting from stimulation of superior laryngeal nerve. Pediatrics 1978;61:519-27.

22. Lawson EE. Prolonged central respiratory inhibition following reflex-induced apnea. J Appl Physiol 1981;50:874-9.

23. Eldridge FL. Relationship between phrenic nerve activity and ventilation. Am J Physiol 1971;221:535-43.

24. Lanier B, Richardson MA, Cummings C. Effect of hypoxia on laryngeal reflex apnea - implications for sudden infant death syndrome. Otolaryngol Head Neck Surg 1983;91:597-604.

25. Bauman NM, Sandler AD, Schmidt C, Maher JW, Smith RJH. Reflex lish a temporal relationship between the two. To prove such an association, apneic episodes need to be associated with GER during prolonged esophageal $\mathrm{pH}$ monitoring, which was not observed in our study. Thus, while such an association will need further prospective studies, we believe that many infants presenting with recurrent brief apneic episodes may have underlying silent GER.

laryngospasm induced by stimulation of distal esophageal afferents. Laryngoscope 1994;104:209-14.

26. Jonson P, Salisbury DM, Storey AT. Apnoea induced by stimulation of sensory receptors in the larynx. In: Bosma JF, Showacre J, eds. Symposium on Development of Upper Respiratory Anatomy and Function: Implications for Sudden Infant Death Syndrome [NIH-75-941]. Bethesda: National Institutes of Health, 1975:160-83.

27. Steinschneider A, Weinstein SL, Diamond E. The sudden infant death syndrome and apnea/obstruction during neonatal sleep and feeding. Pediatrics 1982;70:858-63.

28. Sacre L, Vandenplas Y. Gastroesophageal reflux associated with respiratory abnormalities during sleep. J Pediatr Gastroenterol Nutr 1989;9:28-33.

29. See CC, Newman LJ, Berezin S, et al. Gastroesophageal reflux-induced hypoxemia in infants with apparent life-threatening events. Am J Dis Child 1989:143:951-4.

30. Veereman-Wauters G, Bochner A, Van Caillie-Bertrand M. Gastroesophageal reflux in infants with a history of near-miss sudden infant death. J Pediatr Gastroenterol Nutr 1991;12:319-23.

31. McFayden UM, Hendry GM, Simpson H. Gastro-oesophageal reflux in the near-miss sudden infant death syndrome or suspected recurrent aspiration. Arch Dis Child 1983;58:87-91.

32. Andze GO, Brandt ML, St Vil D, Bensoussan AL, Blanchard H. Diagnosis and treatment of gastroesophageal reflux in 500 children with respiratory symptoms: the value of $\mathrm{pH}$ monitoring. J Pediatr Surg 1991;26:295-9.

33. Jeffery HE, Rahilly P, Read DJ. Multiple causes of asphyxia in infants at high risk for sudden infant death. Arch Dis Child 1983;58:92-100.

34. Schwarz SM, Berezin S, Dozor AJ, Glassman MS, Newman LJ. Gastroesophageal reflux (GER) in infants with apparent life-threatening events (ALTE). Pediatr Res 1988;23:312.

35. Downing SE, Lee JC. Laryngeal chemosensitivity: a possible mechanism for sudden infant death. Pediatrics 1975;55:640-9.

36. Harned HS Jr, Myracle J, Ferreiro J. Respiratory suppression and swallowing from introduction of fluids into the laryngeal region of the lamb. Pediatr Res 1978;12:1003-9.

37. Wetmore RF. Effects of the acid on the larynx of the maturing rabbit and their possible significance to the sudden infant death syndrome. Laryngoscope 1993;103:1242-54.

38. Plaxico DT, Loughlin GM. Nasopharyngeal reflux and neonatal apnea. Am J Dis Child 1981;135:793-4.

39. Kenigsberg K, Griswold PG, Buckley BJ, Gootman N, Gootman PM. Cardiac effects of esophageal stimulation: possible relationship between gastroesophageal reflux (GER) and sudden infant death syndrome (SIDS). J Pediatr Surg 1983;18:542-5.

40. Beyaert C, Marchal F, Dousset B, Serres MA, Monin P. Gastroesophageal reflux and acute life-threatening episodes: role of a central respiratory depression. Biol Neonate 1995;68:87-90.

41. Myer EC, Morris DL, Adams ML, Brase DA, Dewey WL. Increased cerebrospinal fluid beta-endorphin immunoreactivity in infants with apnea and in siblings of victims of sudden infant death syndrome. J Pediatr 1987;111:660-6.

42. Bethmann O, Couchard M, Ajuriaguerra M, et al. Role of gastroesophageal reflux and vagal overreactivity in apparent life-threatening events: 160 cases. Acta Pediatr 1993;389(Suppl 82):102-4.

43. Menon AP, Schefft GL, Thach BT. Airway protective and abdominal expulsive mechanisms in infantile regurgitation. J Appl Physiol 1985;59:716-21.

44. Davies AM, Koenig JS, Thach BT. Characteristics of upper airway chemoreflex prolonged apnea in human infants. Am Rev Respir Dis 1989;139:668-73.

45. Shannon DC, Kelly DH. SIDS and near SIDS (second of two parts). N Engl J Med 1982;306:1022-8. 


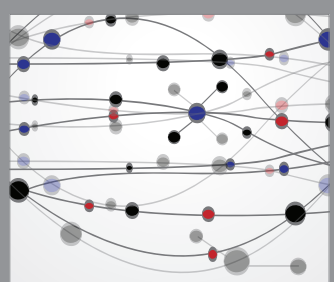

The Scientific World Journal
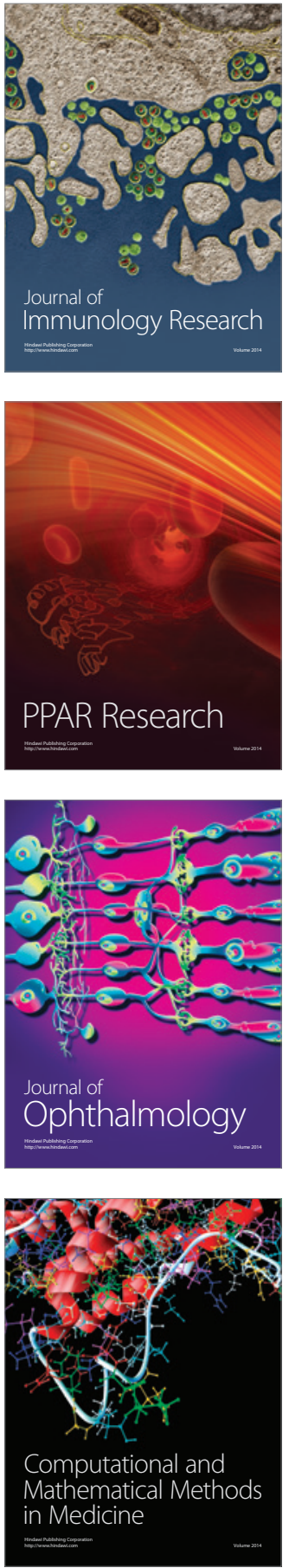

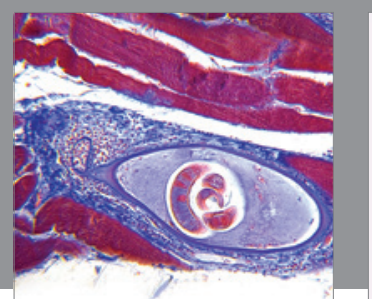

Gastroenterology Research and Practice

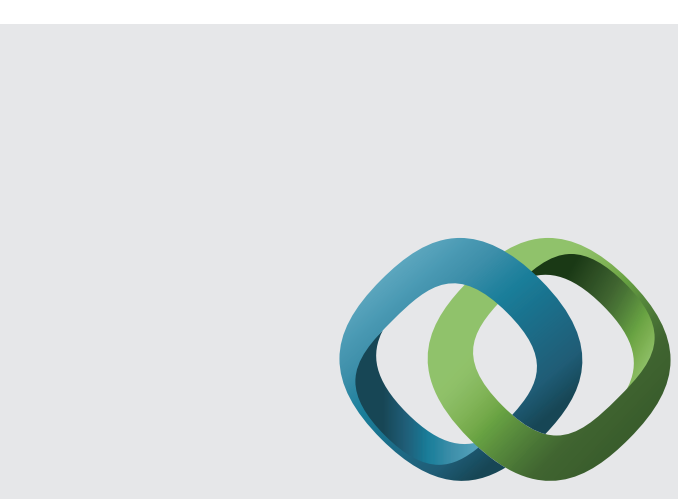

\section{Hindawi}

Submit your manuscripts at

http://www.hindawi.com
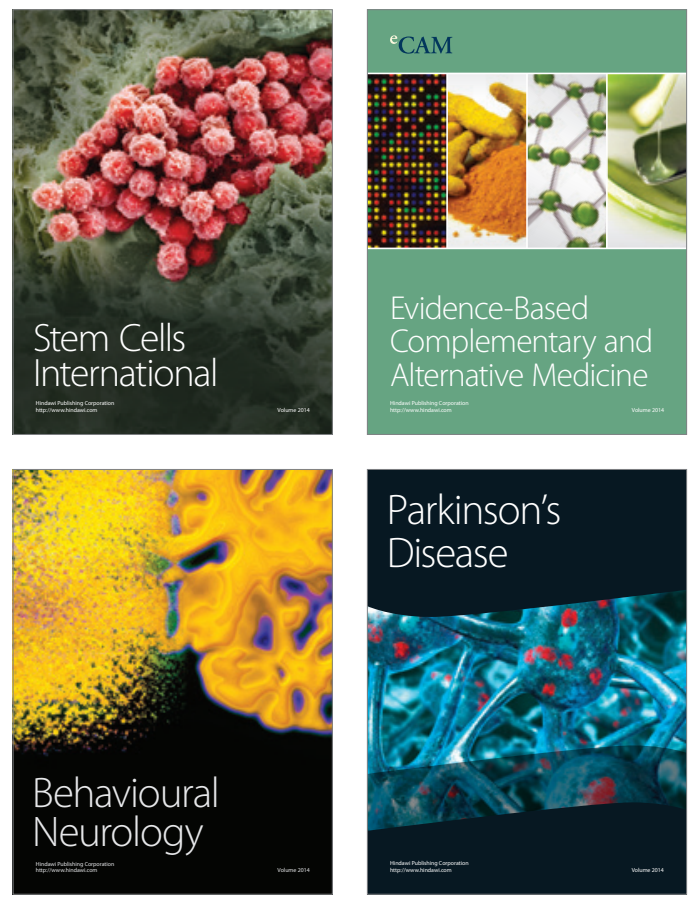
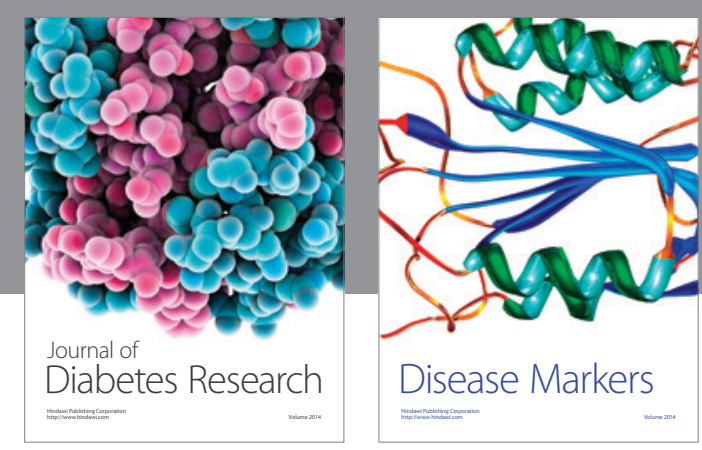

Disease Markers
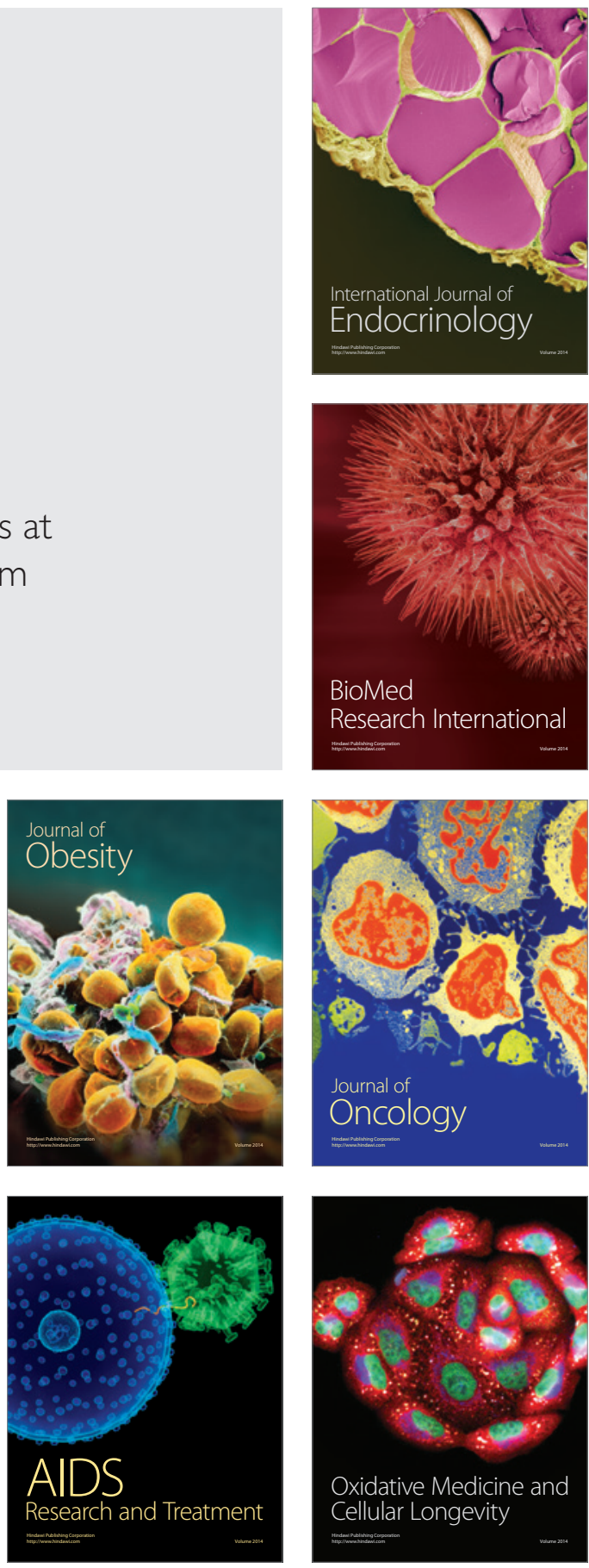